\title{
Cytogenetic Studies on Metaphase Chromosomes of Six Bivalve Species of Families Mytilidae and Veneridae (Nucinelloidea, Mollusca)
}

\author{
Abdel-Basset M. Ebied ${ }^{1}$ and Fayza M. Aly ${ }^{2, *}$ \\ ${ }^{1}$ Cytogenetic Laboratory, Zoology Department, Faculty of Science (Qena), South Valley University, Egypt \\ ${ }^{2}$ Zoology Department, Faculty of Science (Qena), South Valley University, Egypt
}

Received December 8, 2003; accepted April 3, 2004

\begin{abstract}
Summary Chromosomes of 6 bivalve species were studied from mitotic metaphases using cell suspension techniques. Among Family Mytilidae, Modiolus barbatus (Linnaeus 1758) has a diploid chromosome number of $2 n=32$ with 5 metacentric, 2 submetacentric, 5 subtelocentric and 4 telocentric chromosome pairs, Septifer excisus (Wiegmann 1837) has $2 n=26$ with 9 metacentric, 2 submetacentric, and 2 telocentric chromosome pairs and Septifer bilocularis (Linnaeus 1758) also has $2 n=26$ with 8 metacentric, 2 submetacentric and 3 subtelocentric chromosome pairs. Among Family Veneridae, Ruditapes decussatus (Linnaeus 1758) has $2 n=38$ with 6 metacentric, 5 submetacentric, 3 subtelocentric and 5 telocentric chromosome pairs, Circe scripta (Linnaeus 1758) has $2 n=38$ with 6 metacentric, 6 submetacentric, 4 subtelocentric and 3 telocentric chromosome pairs and Venus verrucosa (Linnaeus 1758) has also $2 n=38$ with 7 metacentric, 4 submetacentric, 4 subtelocentric and 4 telocentric chromosome pairs. These results are reported for the first time in Egypt.
\end{abstract}

Key words Chromosomes, Karyotypes, Ideograms, Mytilidae, Veneridae, Bivalvia.

The bases of cytotaxonomy were laid down when the principle of chromosome individuality was accepted and the chromosome theory of heredity became established. It was noticed that the karyotype characterized by the chromosome number, size and morphology, is a definite and constant feature of each species. Since 1992, new karyological data have been added for 65 bivalve species among which the first karyological data are given for 49 species. Within the bivalve class, the most frequent chromosome number of $2 n=38$ was reported by Nakamura (1985) and ThiriotQuievreux (1994).

Chromosome studies have been reported on 14 species of Family Veneridae: the chromosome number $2 n=38$ is most frequently (Menzel 1968a, Gerard 1978, Rasotto et al. 1981, Wang et al. 1998), while chromosome number and morphology (Koulman and Wolff 1977, Corni and Trentini 1990), karyotype (Ieyama 1990) and karyometric analysis (Ieyama 1985, Borsa and ThiriotQuievreux 1990) are described.

The diploid chromosome number ( $2 n)$ of 30 bivalve species (Family: Mytilidae) range from 22 to 32. This diploid chromosome complements have all types of chromosome, and the total diploid chromosome length has been reported mostly from the Mytilidae and shows an increase as $2 n$ increase. The karyotype variety is very apparent in the Mytilidae (Ahmed 1974, Diupotex-Chong et al. 1978, Ieyama 1984, Thiriot-Quievreux 1984, Cornet 1993, Pasantes et al. 1996, Holland et al. 1999, Vitturi et al. 2000, Thiriot-Quievreux 2002). Previous data are compiled in Table 1.

This report presents the chromosome numbers, karyotypes and morphometric measurements of chromosomes in 3 species of Family Mytilidae, Modiolus barbatus, Septifer excesis and Septifer bilocularis and 3 species of Family Veneridae, Ruditopes decussatus, Circe scripta and Venus verrucosa, specially in Egypt. These outcomes are compiled in Table 2.

\footnotetext{
* Corresponding author
} 
Table 1. Interspecific comparisons of karyological data

\begin{tabular}{|c|c|c|c|c|}
\hline Species/Family & Origin & $2 n$ & Karyotype & Reference \\
\hline \multicolumn{5}{|l|}{ Mytilidae } \\
\hline Septifer bilocularis & Japan & 26 & $3 \mathrm{~m}, 2 \mathrm{~m} / \mathrm{sm}, 7 \mathrm{st}, 1 \mathrm{t}$ & Ieyama $1983 b$ \\
\hline Septifer excisus & Japan & 26 & $2 \mathrm{~m}, 1 \mathrm{~m} / \mathrm{sm}, 2 \mathrm{sm}, 7 \mathrm{st}, 1 \mathrm{t}$ & Ieyama $1983 b$ \\
\hline Septifer keenae & Japan & 28 & $3 \mathrm{~m}, 2 \mathrm{~m} / \mathrm{sm}, 2 \mathrm{sm}, 4 \mathrm{st}, 2 \mathrm{t} / \mathrm{st}, 1 \mathrm{t}$ & Ieyama $1983 b$ \\
\hline Septifer virgatus & Japan & 28 & $4 \mathrm{~m}, 1 \mathrm{~m} / \mathrm{sm}, 2 \mathrm{sm}, 4 \mathrm{st}, 1 \mathrm{t} / \mathrm{st}, 2 \mathrm{t}$ & Ieyama $1983 b$ \\
\hline Modiolus barbatus & Italy & 32 & $6 \mathrm{~m}, 8 \mathrm{sm}, 2 \mathrm{st}$ & Libertini et al. 1996 \\
\hline Modiolus barbatus & Italy & 32 & & Rasotto et al. 1981 \\
\hline Modiolus arcuatulus & Egypt & 24 & $5 \mathrm{~m}, 7 \mathrm{sm}$ & Ghobashy et al. 1995 \\
\hline Modiolus arcuatulus & Japan & 32 & $6 \mathrm{~m}, 6 \mathrm{sm}, 3 \mathrm{st}, 1 \mathrm{t}$ & Ieyama $1984 \mathrm{c}$ \\
\hline Mytilus edulis & France & 28 & $6 \mathrm{~m}, 8 \mathrm{sm} / \mathrm{st}$ & Martinez-Lage et al. 1996 \\
\hline Mytilus edulis & France & 28 & $2 \mathrm{~m}, 6 \mathrm{sm}, 6 \mathrm{st}$ & Thiriot-Quievreux and Ayraud 1982 \\
\hline Mytilus galloprovincialis & Spain & 28 & $6 \mathrm{~m}, 8 \mathrm{sm} / \mathrm{st}$ & Martinez-Lage et al. 1994 \\
\hline Mytilus galloprovincialis & France & 28 & $1 \mathrm{~m}, 6 \mathrm{sm}, 7 \mathrm{st}$ & Thiriot-Quievreux and Ayraud 1982 \\
\hline Mytilus trossulus & Canada & 28 & & Gonzalez-Tizon et al. $2000 \mathrm{~b}$ \\
\hline Mytilus trossulus & Canada & 28 & $7 \mathrm{~m}, 7 \mathrm{sm}$ & Martinez-Lage et al. 1997 \\
\hline Mytilus californianus & Canada & 28 & $7 \mathrm{~m}, 7 \mathrm{sm}$ & Martinez-Lage et al. 1997 \\
\hline Mytilus coruscus & Japan & 28 & $5 \mathrm{~m}, 3 \mathrm{sm}, 6 \mathrm{st}$ & Ieyama $1984 c$ \\
\hline Mytilus desolations & Indean & 28 & $5 \mathrm{~m}, 2 \mathrm{~m} / \mathrm{sm}, 4 \mathrm{sm} / \mathrm{st}, 3 \mathrm{st}$ & Thiriot-Quievreux 1984 \\
\hline Brachidontes minimus & $\begin{array}{l}\text { W Medit } \\
\text { erranean }\end{array}$ & 28 & $5 \mathrm{~m}, 9 \mathrm{st}$ & Thiriot-Quievreux, unpublished \\
\hline Brachidontes pharaonis & $\begin{array}{l}\text { S Medit } \\
\text { erranean }\end{array}$ & 28 & $6 \mathrm{~m} / \mathrm{sm}, 8 \mathrm{st}$ & Vitturi et al. 2000 \\
\hline Brachidontes rodriguezi & Argentina & 28 & $2 \mathrm{~m}, 12 \mathrm{st}, 2 \mathrm{t}$ & Torreiro et al. 1999 \\
\hline \multicolumn{5}{|l|}{ Veneridae } \\
\hline Circe scripta & Japan & 38 & $19 \mathrm{~m}$ & Ieyama 1980 \\
\hline Venus verrucosa & Italy & 38 & & Rasotto et al. 1981 \\
\hline Ruditopes decussatus & Spain & 38 & & Rodriguez-Juiz et al. 1996 \\
\hline Ruditopes decussatus & France & 38 & $9 \mathrm{~m} / \mathrm{sm}, 10 \mathrm{st} / \mathrm{t}$ & Borsa and Thiriot 1990 \\
\hline Ruditopes philippinarum & Canada & 38 & & Gonzalez-Tizon et al. 2000b \\
\hline Ruditopes aureus & France & 38 & $17 \mathrm{~m} / \mathrm{sm}, 2 \mathrm{st} / \mathrm{t}$ & Borsa and Thiriot 1990 \\
\hline Venerupis pullastra & Spain & 38 & $3 \mathrm{~m}, 8 \mathrm{sm}, 8 \mathrm{st}$ & Insua and Thiriot-Quievreux 1992 \\
\hline Venerupis rhomboides & Spain & 38 & $4 \mathrm{~m}, 8 \mathrm{sm}, 4 \mathrm{st}, 3 \mathrm{t}$ & Insua and Thiriot-Quievreux 1992 \\
\hline Chione cancellata & USA & 38 & & Menzel 1968a \\
\hline Irus mitis & Japan & 38 & $15 \mathrm{~m}, 4 \mathrm{sm}$ & Ieyama 1980 \\
\hline
\end{tabular}

$\mathrm{m}$ : metacentric, sm: submetacentric, st: subtelocentric, t: telocentric.

Table 2. Summary of karyological data of the present study

\begin{tabular}{|c|c|c|c|c|c|c|c|c|}
\hline \multirow{2}{*}{ Family/Species } & \multirow{2}{*}{$2 n$} & \multicolumn{6}{|c|}{ Karyotype } & \multirow{2}{*}{ Reference } \\
\hline & & $\mathrm{m}$ & $\mathrm{m} / \mathrm{sm}$ & $\mathrm{sm}$ & st & $\mathrm{st} / \mathrm{t}$ & $\mathrm{t}$ & \\
\hline \multicolumn{9}{|l|}{ Mytilidae } \\
\hline Septifer bilocularis & 26 & 3 & 2 & & 7 & & 1 & Ieyama $1983 b$ \\
\hline Septifer bilocularis & 26 & 8 & & 2 & 3 & & & Present study \\
\hline Septifer excisus & 26 & 2 & 1 & 2 & 7 & & 1 & Ieyama $1983 b$ \\
\hline Septifer excisus & 26 & 9 & & 2 & & & 2 & Present study \\
\hline Modiolus barbatus & 32 & 6 & & 8 & 2 & & & Libertini et al. 1996 \\
\hline Modiolus barbatus & 32 & 5 & & 2 & 5 & & 4 & Present study \\
\hline \multicolumn{9}{|l|}{ Veneridae } \\
\hline Circe scripta & 38 & 19 & & & & & & Ieyama 1980 \\
\hline Circe scripta & 38 & 6 & & 6 & 4 & & 3 & Present study \\
\hline Ruditopes decussatus & 38 & & 9 & & & 10 & & Borsa and Thiriot 1990 \\
\hline Ruditopes decussatus & 38 & 6 & & 5 & 3 & & 5 & Present study \\
\hline Venus verrucosa & 38 & & & & & & & Rasotto et al. 1981 \\
\hline Venus verrucosa & 38 & 7 & & 4 & 4 & & 4 & Present study \\
\hline
\end{tabular}

$\mathrm{m}$ : metacentric, sm: submetacentric, st: subtelocentric, t: telocentric. 


\section{Materials and methods}

Samples of the different species investigated were collected from different localities along the coast of the Red Sea from Hurghada to Quseir City. The collected specimens were transferred directly to the laboratory and kept alive in tanks of aerated seawater.

The whole animals were prepared by the warm-dry method of Kligerman and Bloom (1977) with some modification made by Nakamura (1986) as follows: The bivalves were kept in $0.005 \%$ colchicine solution for $2-6 \mathrm{~h}$ before being sacrificed, and then the gonads and gills were removed, cut into small pieces and soaked in $0.075 \mathrm{~m} \mathrm{KCl}$ hypotonic solution. These pieces were fixed in freshly mixed Carnoy's fixative ( $3: 1$ methyl alcohol : acetic acid) with 3 changes of 20 min duration. Tissues were then minced gently in $50 \%$ acetic acid to prepare a cell suspension. A drop of the cell suspension was pipetted out and placed on heated clean glass slides. For conventional karyotypes, slides were stained directly with Giemsa (4\% in phosphate buffer, pH 6.8) for $20 \mathrm{~min}$.

The best spread chromosome configurations were cut out from the photographs and chromosomes were paired on the basis of centromeric position and size for karyotyping. The following morphological features were used to compare the karyotypes: the relative length $(\mathrm{Rl})$, the arm ratio (Ar) and the centromeric index (Ci). Fundamental number (FN) was calculated on the basis that metacentric, submetacentric and subtelocentric having a value of four and acrocentric has a value of two. Nomenclature of chromosome type adopted by Levan et al. (1964) were used in the present study.

\section{Results and discussion}

\section{Modiolus barbatus}

The chromosome number from the species Modiolus barbatus was determined from gills,

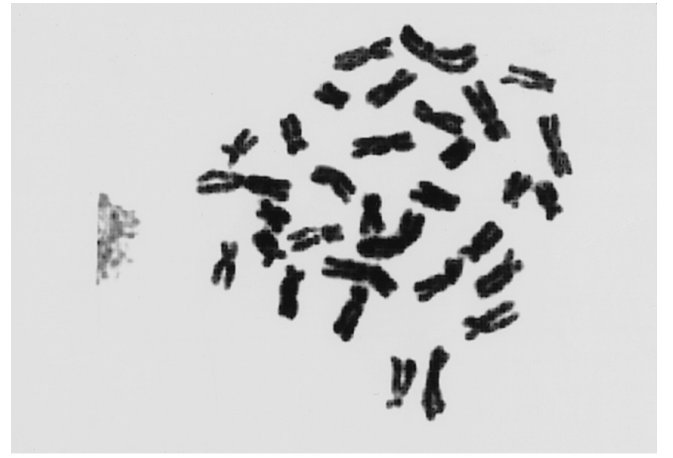

(a)

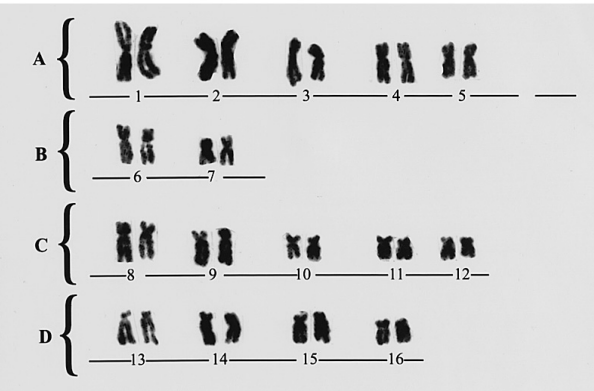

(b)

Fig. 1. Mitotic metaphase spread (a) and karyotype (b) of Modiolus barbatus $2 n=32$.
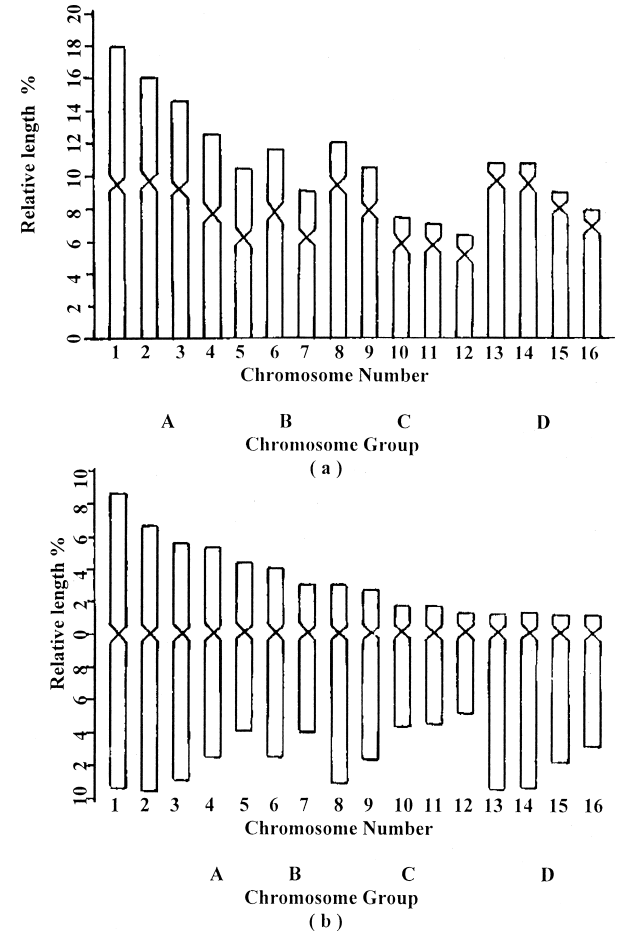

Fig. 2. Ideograms of the chromosomes of Modiolus barbatus constructed with respect to the relative length (a) and the centromeric index (b). 
oogonial and spermatogonial germ line cells; gills offered better results for chromosomal analysis than gonads. The photograph of the cell spread and the karyotype of this species showed that it has a diploid chromosome number of $2 n=32$ with fundamental number (FN) of 56 (Fig. 1a). An ideogram (Fig. 2a, b) was constructed from the relative length and centromeric indices with the centromere drawn at the same level to make the visual comparison easier.

The karyotype of Modiolus barbatus show 4 different groups of chromosomes (Fig. 1b). Group A is composed of 5 metacentric chromosome pairs with an arm ratio ranging from 1.09 to 1.64 , relative length from $6.02 \%$ to $10.42 \%$ and centromeric index variying from 37.93 to 47.78 . Group B has 2 submetacentric chromosome pairs with an arm ratio ranging from 1.88 to 2.00, relative length from $5.21 \%$ to $6.65 \%$ and centromeric index variying from 33.33 to 34.78 . Group C consists of 5 subtelocentric chromosome pairs with an arm ratio ranging from 3.12 to 4.17 , relative length from $4.05 \%$ to $6.95 \%$ and centromeric index variying from 19.35 to 24.27 and group D contains 4 telocentric chromosome pairs with arm ratio ranging from 7.67 to 9.60 , relative length from $4.51 \%$ to $6.13 \%$ and centromeric index variying from 9.43 to 11.54 (Table 3). The diploid chromosome number of Modiolus barbatus $2 n=32$ is in agreement with that reported by Libertini et al. (1996). While the karyotype reported by them is composed of 6 metacentric, 8 submetacentric and 2 subtelocentric chromosome pairs, that of our result composed of 5 metacentric, 2 submetacentric, 5 subtelocentric and 4 telocentric chromosome pairs.

\section{Septifer excisus}

The cell spread, karyotype and ideogram of a model sample of this species (Fig. 3, 4) demon-

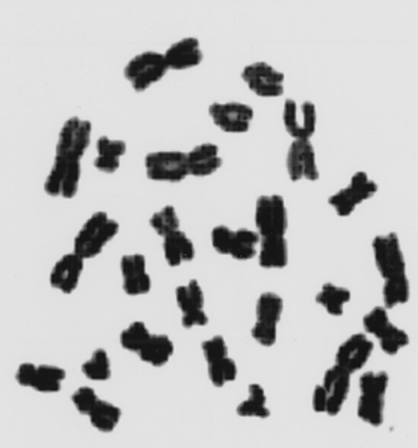

(a)

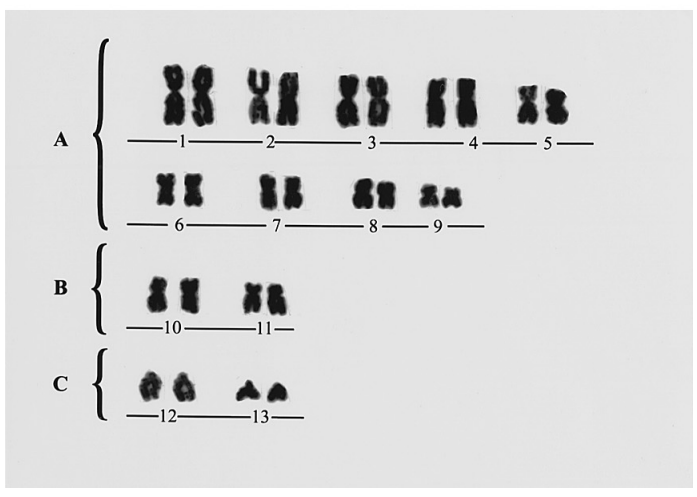

(b)

Fig. 3. Mitotic metaphase spread (a) and karyotype (b) of Septifera excisus $2 n=26$.

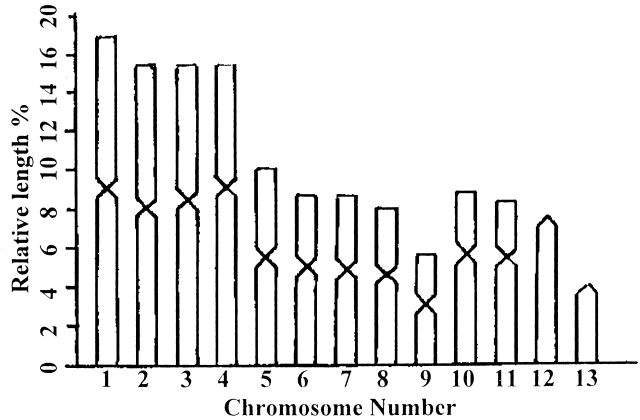

A Chromosome Group

(a)

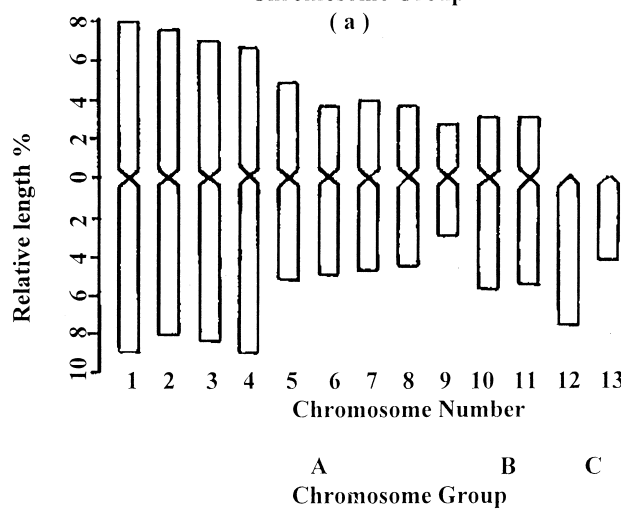

(b)

Fig. 4. Ideograms of the chromosomes of Septifer exciss which were constructed in respect to the relative length (a) and the centromeric index (b). 

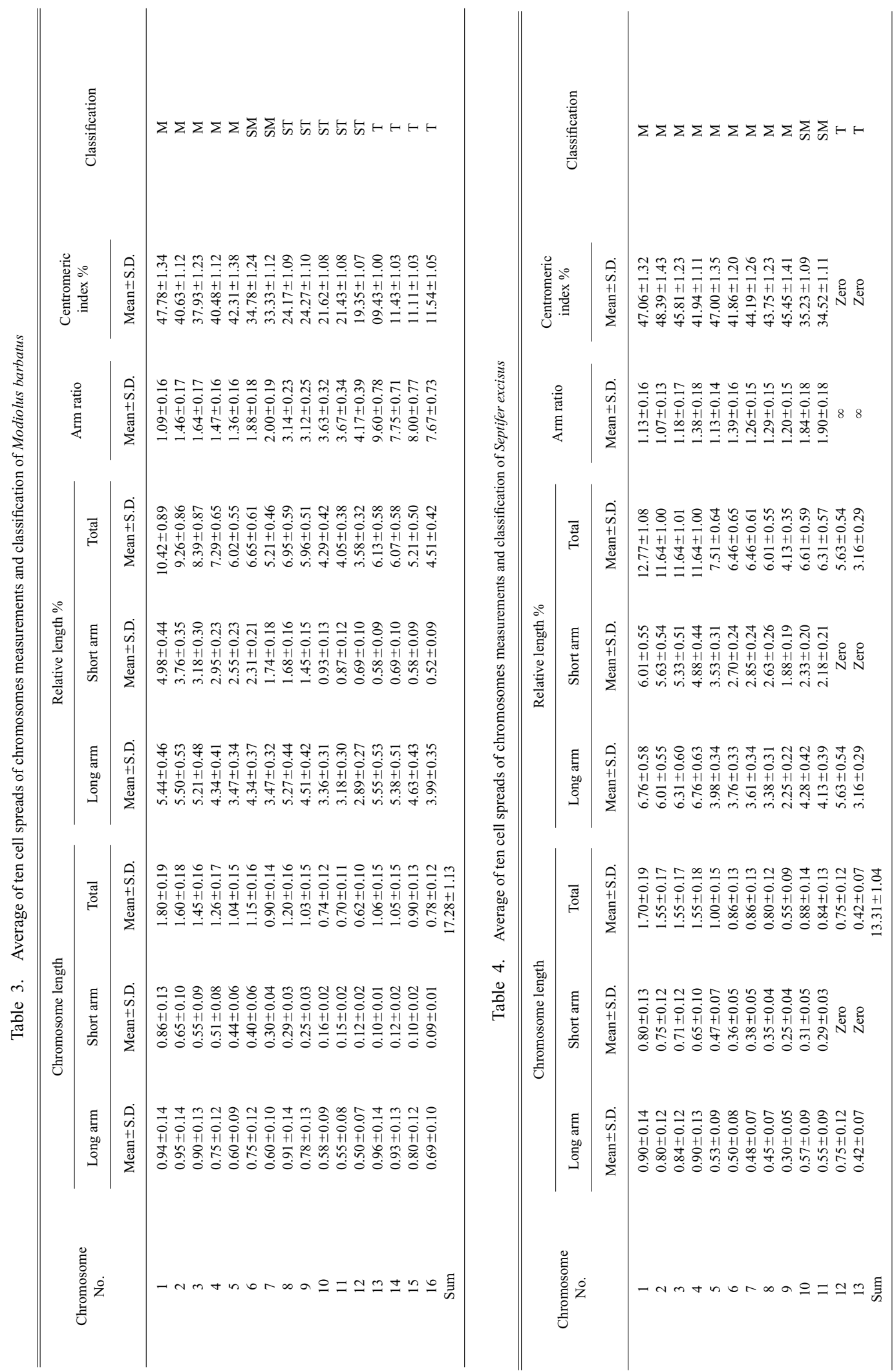
strate that the diploid chromosome number is $2 n=26$ and the fundamental number is $\mathrm{FN}=48$. These chromosomes consist of three groups: Group A which contains 9 metacentric chromosome pairs with arm ratio ranging from 1.07 to 1.39 , relative length from $4.13 \%$ to $12.77 \%$ and centromeric index from 41.86 to 48.39 . Group B is composed of 2 submetacentric chromosome pairs with arm ratio ranging from 1.84 to 1.90 , relative length from $6.31 \%$ to $6.61 \%$ and centromeric index from 34.52 to 35.23 . Group $\mathrm{C}$ consists of 2 telocentric chromosome pairs with arm ratio being $\infty$, relative length from $3.16 \%$ to $5.63 \%$ and centromeric index being zero (Table 4 ).

The diploid chromosome number of Septifer excisus (Wiegmann 1837) $2 n=26$ is in agreement with that reported by Ieyama (1983). While the previous karyotype is composed of 2 metacentric, one metacentric/submetacentric, 2 submetacentric, 7 subtelocentric and one telocentric chromosome pairs, while that of our result composed of 9 metacentric, 2 submetacentric and 2 telocentric chromosome pairs.

\section{Septifer bilocularis}

The chromosomes of 52 mitotic metaphases taken from 17 animals were counted. 43 cells had $2 n=26$ and fundamental number (FN) of 52 (Fig. 5a). The karyotype consists of 3 groups: Group A consisting of 8 metacentric chromosome pairs with an arm ratio ranging from 1.00 to 1.61, relative length from $5.56 \%$ to $11.12 \%$, and centromeric index from 44.12 to 50.00 . Group B composed of 2 submetacentric chromosome pairs with an arm ratio ranging from 1.73 to 1.92 , relative length from $6.48 \%$ to $11.12 \%$, and centromeric index from 34.29 to 36.67 . Group C contains 3 subtelocentric chromosome pairs with an arm ratio ranging from 3.63 to 4.38 , relative length from $6.86 \%$ to

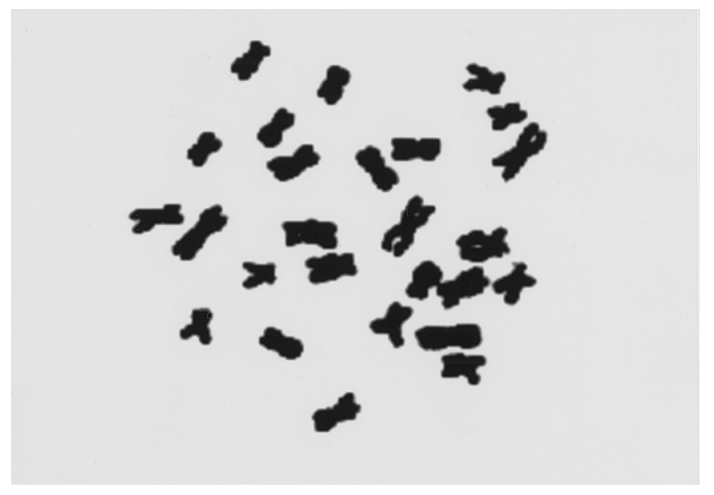

(a)

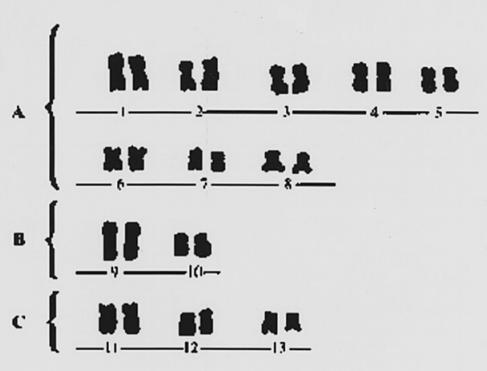

(b)

Fig. 5. Mitotic metaphase spread (a) and karyotype (b) of Septifera bilocularis $2 n=26$.
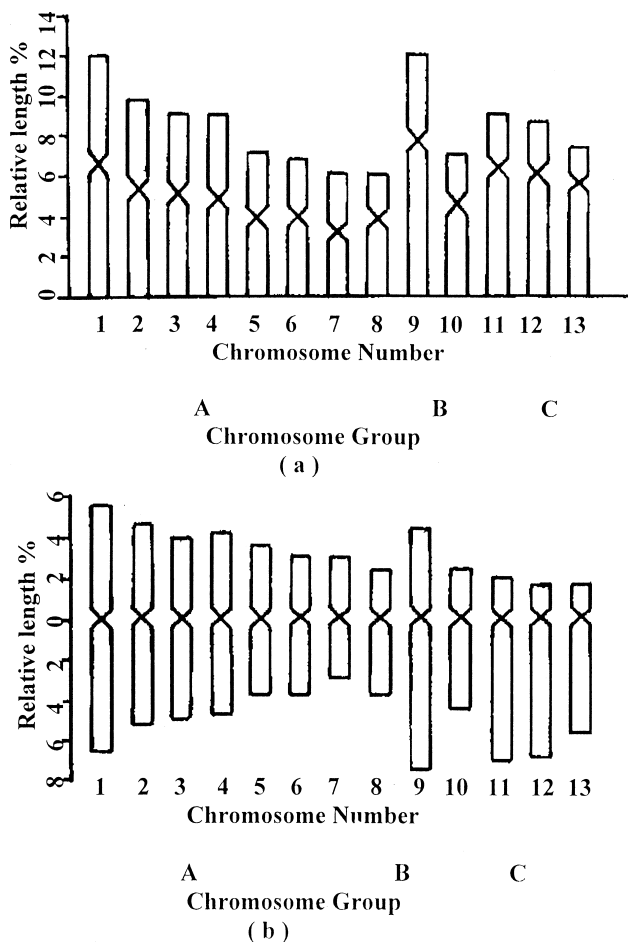

Fig. 6. Ideograms of the chromosomes of Septifer bilocularis which were constructed in respect to relative length (a) and the centromeric index (b). 


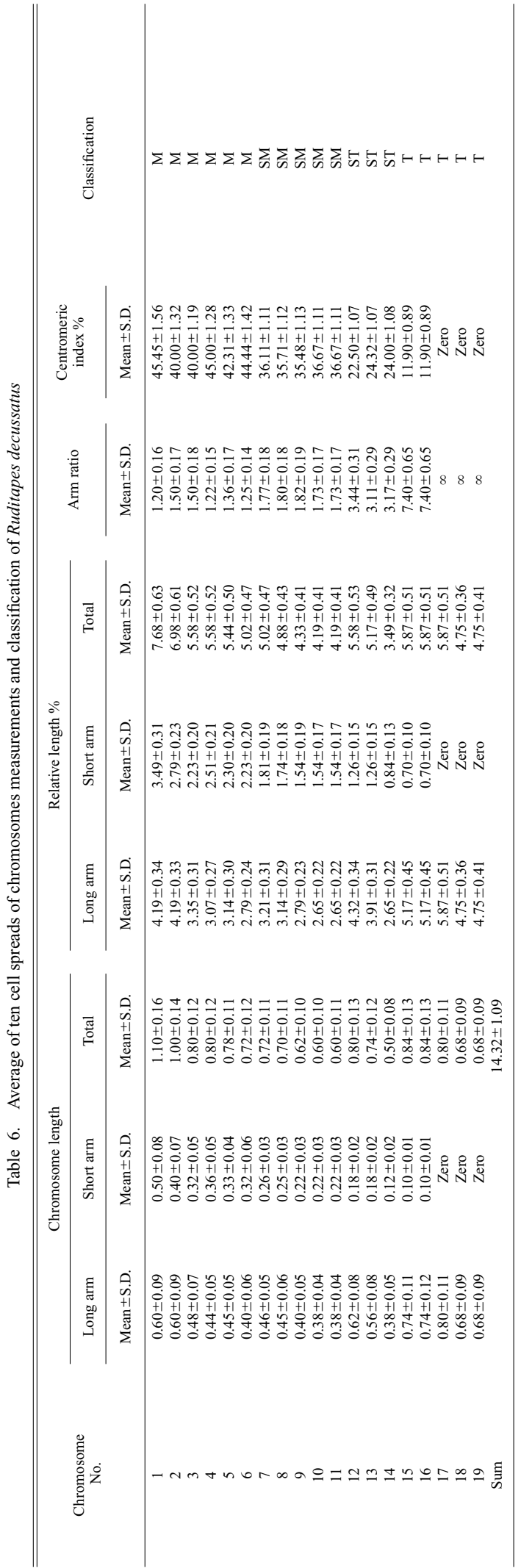


$8.34 \%$, and centromeric index from 18.60 to 21.62 (Fig. 5b, Table 5). The ideograms were constructed (Fig. 6a, b).

The diploid chromosome number of Septifer bilocularis (Linnaeus 1758) $2 n=26$ is in agreement with that reported by Ieyama (1983). While the karyotype that he showed is composed of 3 metacentric, 2 metacentric/submetacentric, 7 subtelocentric and one telocentric chromosome pairs, our karyotype was composed of 8 metacentric, 2 submetacentric and 3 subtelocentric chromosome pairs.

The cytogenetic findings of the present investigation of three species Modiolus barbatus, Septifer excesis and Septifer bilocularis, are in complete agreement with those reported using the classical morphological and anatomical methods for taxonomy. The results of these three species are in agreement with those reported by Ahmed 1974, Diupotex-Chong et al. 1978, Ieyama 1984, ThiriotQuievreux 1984, Cornet 1993, Pasantes et al. 1996, Holland et al. 1999, Vitturi et al. 2000, ThiriotQuievreux 2002 in which they reported that the diploid chromosome number of Family Mytilidae to which Modiolus barbatus, Septifer excesis and Septifer bilocularis belonge ranges from $2 n=22$ to $2 n=32$.

\section{Ruditapes decussatus}

A diploid composition of $2 n=38$ was found in 46 mitotic metaphase from 18 animals (Fig. 7a). For karyotyping, chromosomes of 10 well-spread metaphase plates were cut out from photomicrographs and paired on the basis of size and centromeric position. Chromosome measurements were taken from the 10 best spreads and the means and SD of length of short arm and long arm,

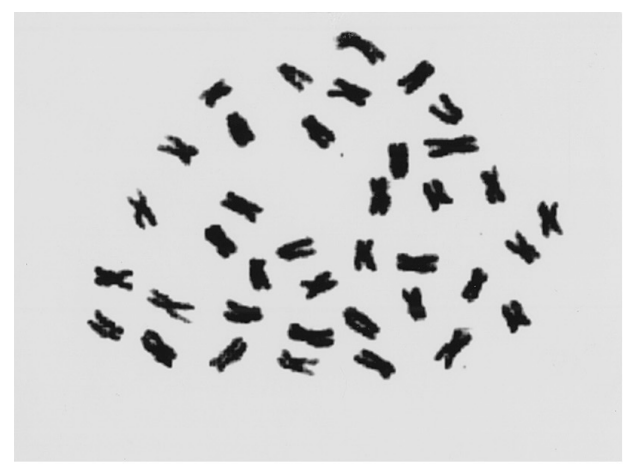

(a)

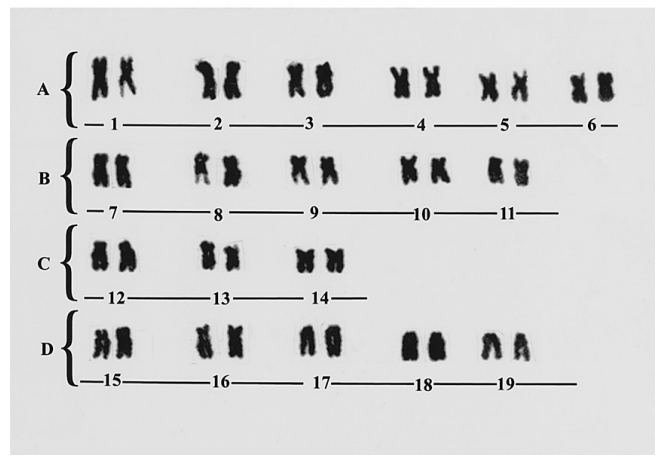

(b)

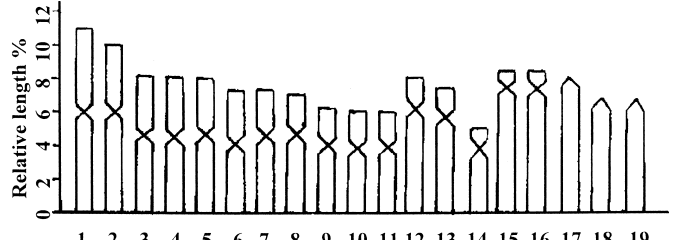

$\begin{array}{lllllllllllllllllll}1 & 2 & 3 & 4 & 5 & 6 & 7 & 8 & 9 & 10 & 11 & 12 & 13 & 14 & 15 & 16 & 17 & 18 & 19\end{array}$ Chromosome Number

A B
Chromosome Group
(a)

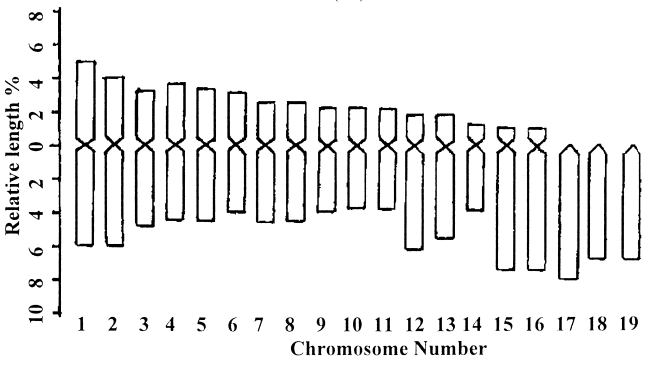

A
D

Fig. 8. Ideograms of the chromosomes of Ruditapes decussates which were constructed in respect to relative length (a) and the centromeric index (b).

Fig. 7. Mitotic metaphase spread (a) and karyotype (b) of Ruditapes decussatus $2 n=38$. 
chromosome length, relative length $(100 \times$ absolute chromosome pair length/total length of haploid complement), arm ratio (length of short arm/length of long arm) and centromeric index ( $100 \times$ length of short arm/total length of chromosome) together with the chromosome classification are given in Table 6 .

The karyotype consists of four groups (Fig. 7b): Group A consists of 6 metacentric chromosome pairs with relative length ranging from $5.02 \%$ to $7.68 \%$, arm ratio from 1.20 to 1.50 and centromeric index varies from 40.00 to 45.45 . Group B which composed of 5 submetacentric chromosome pairs with relative length ranging from $4.19 \%$ to $5.02 \%$, arm ratio from 1.73 to 1.82 and centromeric index varies from 35.48 to 36.67 . Group C has 3 subtelocentric chromosome pairs with relative length ranging from $3.49 \%$ to $5.58 \%$, arm ratio from 3.11 to 3.44 and centromeric index varies from 22.50 to 24.32 . Group D which contains 5 telocentric chromosome pairs with relative length ranging from $4.75 \%$ to $5.87 \%$, arm ratio from 7.40 to $\infty$ and centromeric index varies from zero to 11.90 (Table 6). An ideogram ( Fig. 8a, b) was constructed from relative length and centromeric indices with the centromers drawn at the same level to make visual comparison easier.

The diploid chromosome number of Ruditapes decussatus (Linnaeus 1758) $2 n=38$ is in agreement with that reported by Borsa and Thiriot-Quievreux (1990). While the karyotype that they reported is composed of 9 metacentric/submetacentric and 10 subtelocentric/telocentric chromosome pairs, that of our result composed of 6 metacentric, 5 submetacentric, 3 subtelocentric and 5 telocentric chromosome pairs.

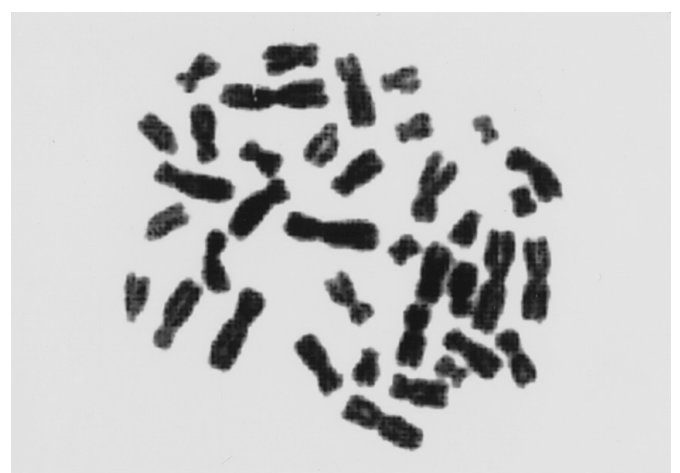

(a)

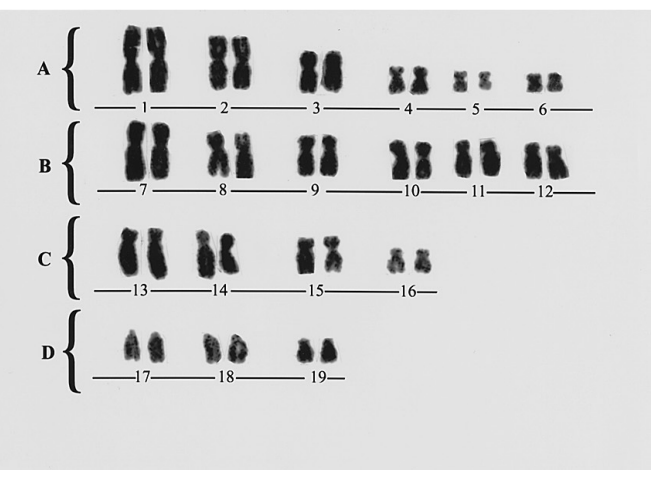

(b)

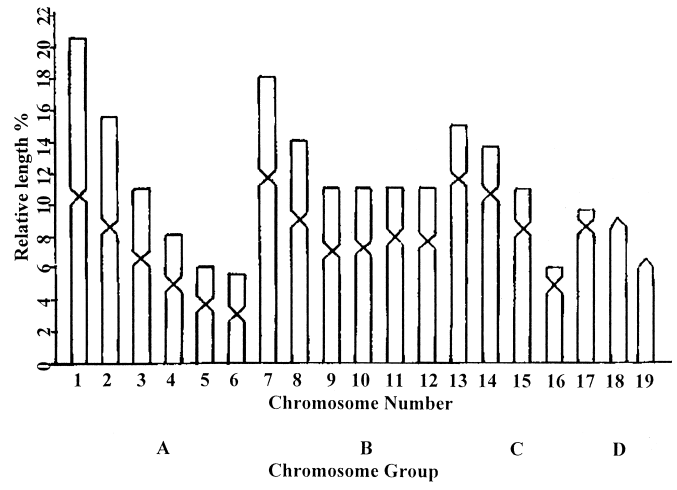

(a)

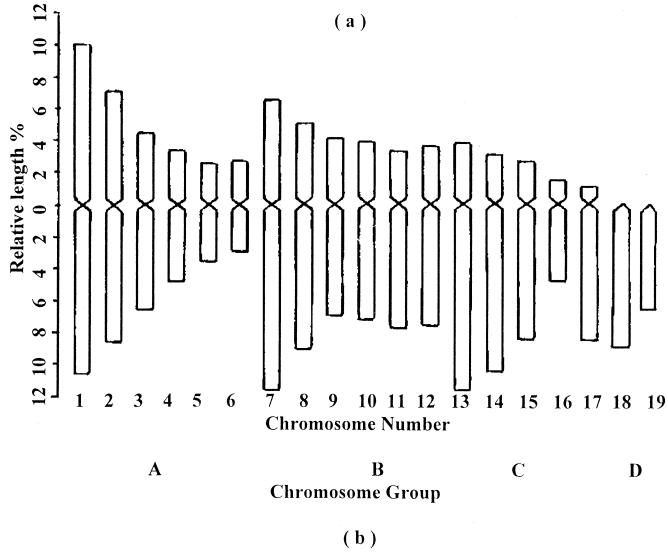

Fig. 10. Ideograms of the chromosomes of Circe scripta

\footnotetext{
which were constructed in respect to relative length (a) and the centromeric index (b).
}

Fig. 9. Mitotic metaphase spread (a) and karyotype (b) of Circe scripta $2 n=38$. 

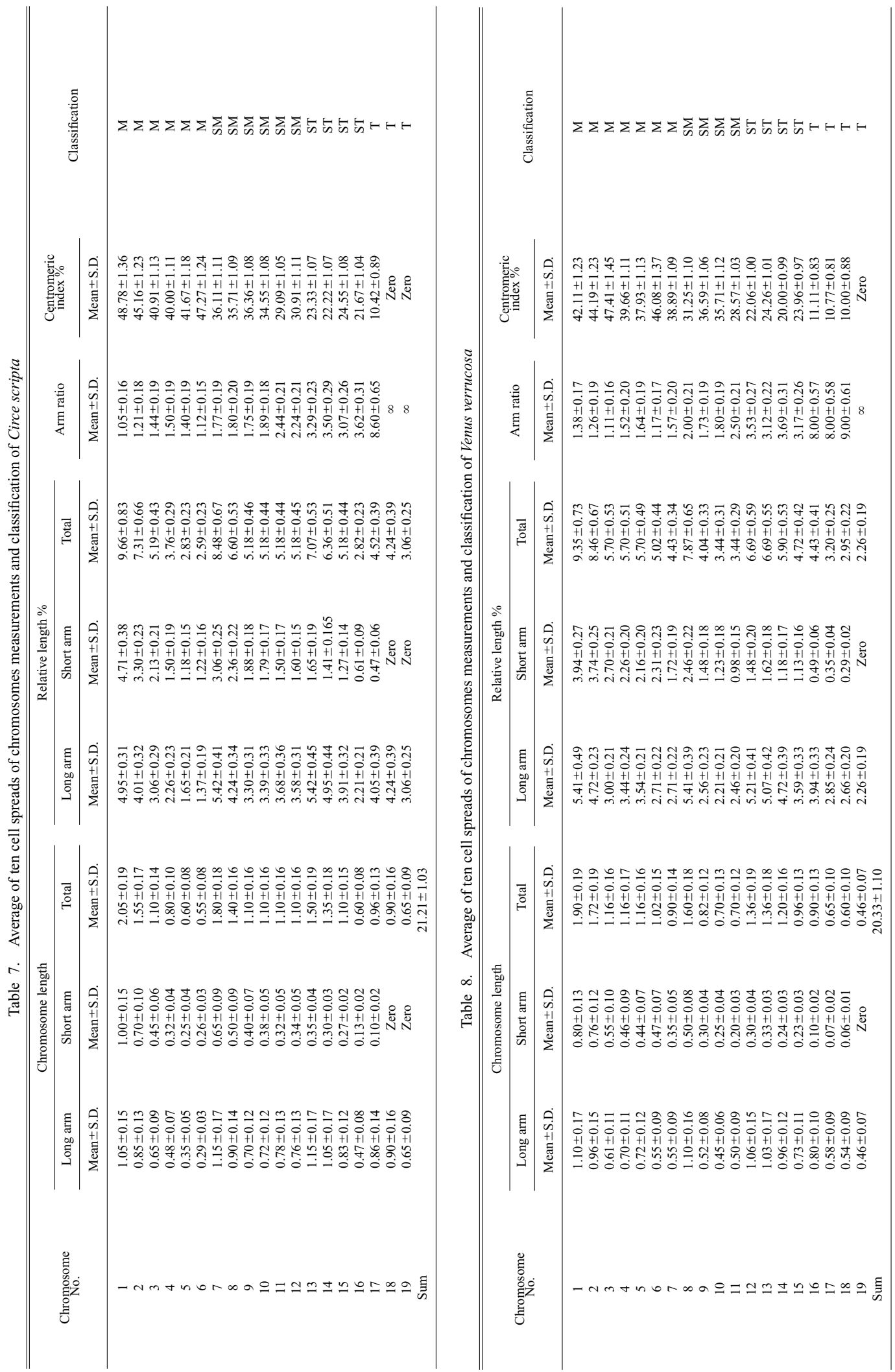


\section{Circe scripta}

The chromosomes of 37 mitotic metaphases taken from 15 animals were counted. 49 cells had $2 n=38$ and fundamental number (FN) of 72 (Fig. 9a). The karyotype consists of four groups: Group A consisting of 6 metacentric chromosome pairs with arm ratio ranging from 1.05 to 1.56 , relative length varies from $2.59 \%$ to $9.66 \%$ and centromeric index from 40.00 to 48.78 . Group B which composed of 6 submetacentric chromosome pairs with arm ratio ranging from 1.75 to 2.44, relative length from $5.18 \%$ to $8.46 \%$, and centromeric index varies from 29.09 to 36.36 . Group C contains 4 subtelocentric chromosome pairs with arm ratio ranging from 3.29 to 3.62 , relative length from $2.82 \%$ to $7.07 \%$, and centromeric index varies from 21.67 to 24.55 . Group D has 3 telocentric chromosome pairs with arm ratio ranging from 8.60 to $\infty$, relative length from $3.06 \%$ to $4.52 \%$, and centromeric index varies from (Fig. 9b, Table 7). An ideogram (Fig. 10a, b) was constructed.

The diploid chromosome number of Circe scripta (Linnaeus 1758) $2 n=38$ is in agreement with that reported by Ieyama (1980). While the karyotype of which is composed of 19 metacentric, that of our result composed of 6 metacentric, 6 submetacentric, 4 subtelocentric and 3 telocentric chromosome pairs.

\section{Venus verrucosa}

A diploid complement of $2 n=38$ was found in 32 mitotic metaphase from 16 animals (Fig. 11a). For karyotyping, the chromosomes of 10 well-spread metaphase plates were cut out from pho-

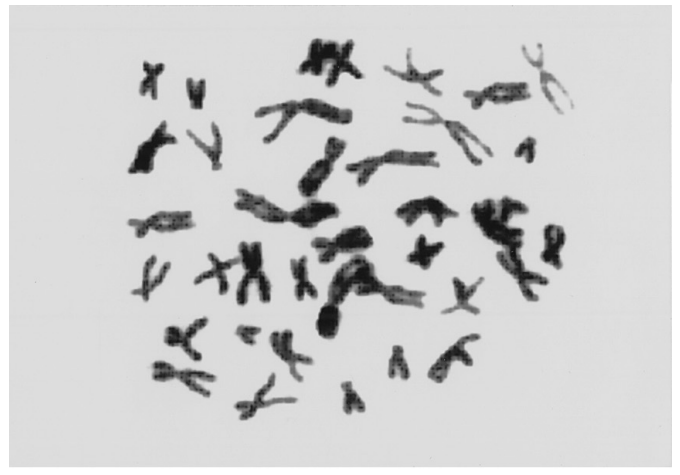

(a)

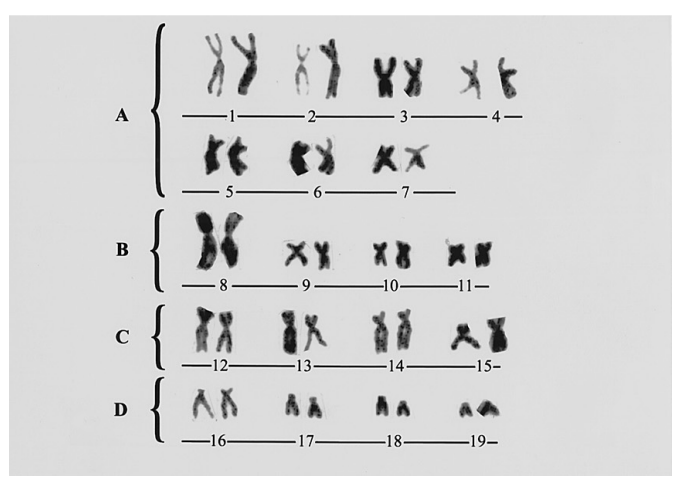

(b)

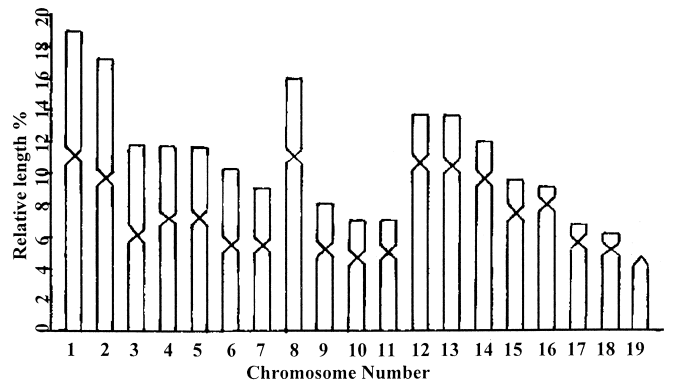

A
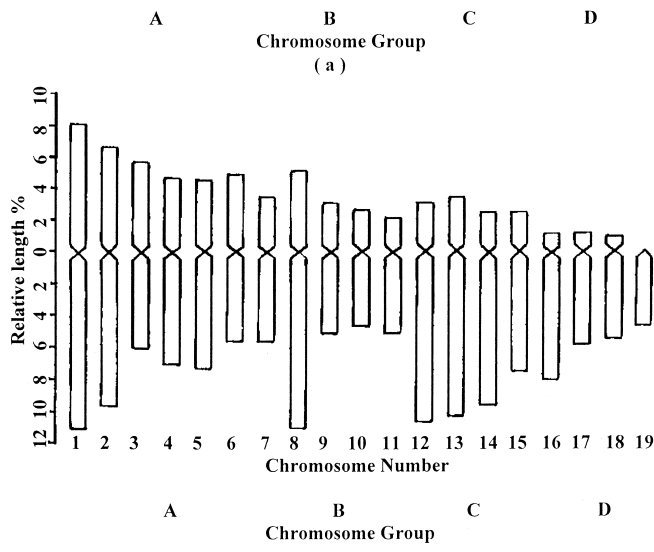

( b )

Fig. 12. Ideograms of the chromosomes of Venus verru-

Fig. 11. Mitotic metaphase spread (a) and karyotype (b) of cosa which were constructed in respect to relative length (a)
Venus verrucosa $2 n=38 . \quad$ and the centromeric index (b). 
tomicrographs and paired on the basis of size and centromeric position.

The karyotype (Fig. 11b) consists of four groups: Group A consists of 7 metacentric chromosome pairs with relative length ranging from $4.43 \%$ to $9.35 \%$, arm ratio from 1.11 to 1.64 and centromeric index varies from 37.93 to 47.41 . Group B which composed of 4 submetacentric chromosome pairs with relative length ranging from $3.44 \%$ to $7.87 \%$, arm ratio from 1.73 to 2.50 and centromeric index varies from 28.57 to 36.59 . Group $\mathrm{C}$ has 4 subtelocentric chromosome pairs with relative length ranging from $4.72 \%$ to $6.69 \%$, arm ratio from 3.12 to 3.69 and centromeric index varies from 20.00 to 23.96 . Group D which contains 4 telocentric chromosome pairs with relative length ranging from $2.26 \%$ to $3.20 \%$, arm ratio from 8.00 to $\infty$ and centromeric index varies from zero to 10.77 (Table 8). An ideogram ( Fig. 12a, b) was constructed. The diploid chromosome number of Venus verrucosa (Linnaeus 1758) $2 n=38$ is in agreement with that reported by Rasotto et al. (1981).

The cytogenetic findings of the present investigation on the 3 species, Ruditopes decussatus, Circe scripta and Venus verrucosa, are in complete agreement with those recorded using the classical morphological and anatomical methods for taxonomy. The results of these three species are in agreement with that reported by (Menzel 1968, Koulman and Wolff 1977, Gerard 1978, Rasotto et al. 1981, Ieyama 1990, Corni and Trentini 1990, Borsa and Thiriot-Quievreux 1990, Wang et al. 1998 ) in which they reported that the most frequently chromosome number of Family Veneridaeto which Ruditopes decussatus, Circe scripta and Venus verrucosa belonged-is $2 n=38$.

\section{REFERENCES}

Ahmed, M. 1974. Chromosomes of two species of marine mussel Perna (Mytilidae: Pelecypoda). Bol. Inst. Oceanogr. Univ. Oriente 13: 17-22.

Borsa, P. C. and Thiriot-Quievreux, C. 1990. Karyological and allozymic charactrization of Ruditopes philippinarum, R. aureus and $R$. decussatus (Bivalvia: Veneridae). Aquaculture 90: 209-227.

Cornet, M. 1993. A short term culture of chromosome preparation from somatic tissues of adult mussels. Experientia 49: 87-90.

Corni, M. G. and Trentini, M. 1990. The Chromosomes of Venerupis aurea and Ruditopes philippinarum of the Northern Adriatic Sea (Bivalvia: Heterodonta: Veneridae). Venus 49: 258-261.

Diuportex-Chong, M. E., Rodriguez-Romero, F., Uribe-Alcocer, M. and Laguarda-Figueras, A. 1978. Karyotype characters of Brachidontes recurvus (Pelecipoda-Mytilidae). An. Cen. Circe. Mar. Limnol. Univ. Nac. Auton. Mex. 5: 55-58.

Gerard, A. 1978. Etude des garnitures chromosomiques de deux Veneridae: Ruditopes decussatus (L.) et Ruditopes philippinarum. Haliotis 9: 69-71.

Ghobashy, A. F. A., Mona, M. H., Yasseen, A. E. and Desouky, M. 1995. A chromosomic study of the marine bivalve Modiolus arcuatulus (Pteriomorphia: Mytilidae). J. Mar. Biol. Association of India 37: 277-280.

Gonzalez-Tizon, A., Martinez-Lage, A., Rego, I., Ausio, J. and Mendez, J. 2000. DNA contents, karyotypes and chromosomal location of $18 \mathrm{~s}-5,8 \mathrm{~s}-28 \mathrm{~s}$ ribosomal loci in some species of bivalve molluscs from the Pacific Canadian Coast. Genome 43: 1065-1072.

Holland, B. S., Gallagher, D. S., Hicks, D. W. and Davis, S. K. 1999. Cytotaxonomic verification of a non-indigenous marine mussel in the Gulf of Mexico. The Veliger 42: 280-282.

Ieyama, H. 1980. Studies on the chromosomes in three species of the Veneridae (Bivalvia: Heterodonta). Venus 39: 49-55.

— 1983. Studies on the chromosomes of four species in the Genus Septifer (Bivalvia: Mytilidae). Venus 42: 193-202.

- 1984. Karyotype in eight species of the Mytilidae (Bivalvia: Pteriomorpha). Venus 43: 240-253.

- 1985. Karyotype in Ruditopes philippinarum (Bivalvia: Veneridae). Sp. Publ. Mukaishima Mar. Biol. St. 83-85.

- 1990. Chromosomes of the oysters, Hyotissa imbricata and Dendrostrea folium (Bivalvia-Pteriomorpha). Malaco 49: 63-68.

Insua, A. and Thiriot-Quievreux, C. 1992. Karyotypes of Cerastoderma edule, Venerupis pullastra and Venerupis rhomboides (Bivalvia-Ostreidae). Aquat. Living Resour. 5: 1-8.

Kligerman, A. D. and Bloom, S. E. 1977. Rapid chromosome preparation from solid tissues of Fishes. J. Fish. Res. Board Can. 34 266-269.

Koulman, J. G. and Wolff, W. S. 1977. The Mollusca of the Estuarine region of the rivers Rhine, Meuse and Scheldt in relation to the hydrography of the area. V. The Cardiidae, Basteria 41: 21-32.

Levan, A., Fredga, K. and Sandberg, A. A. 1964. Nomenclature for centromeric position on chromosomes. Heredity 52: 
201-220

Libertini, A., Boata, A., Panozzo, M. and Fogato, V. 1996. Karyotype and genome size in some species of Mytilidae (Bivalvia-Mollusca). La Kromosomo II 82: 2819-2827.

Martinez-Lage, A., Gonzalez-Tizon, A. and Mendez, J. 1994. Characterization of different chromatin types in Mytilus galloprovincialis L. after C-banding, fluorochrome and restriction endonuclease treatments. Heredity 72: 242-249.

—, - and - 1996. Chromosomes differences between European mussel populations (genus Mytilus). Caryologia 49: 343-355.

—, - Ausio, J. and Mendez, J. 1997. Karyotypes and Ag-NORs of the mussels Mytilus californianus and Mytilus trossulus from the Pacific Canadian Coast. Aquaculture 153: 239-249.

Menzel, R. W. 1968. Chromosome number in nine families of marine pelecypoda mollusks. Nautilus 82: 45-58.

Nakamura, H. K. 1985. A review of molluscan cytogenetic information based on the CISMOCH-computerized system for molluscan chromosome. Bivalvia, Polycophora and Cephalopoda. Venus, Jpn. J. Malacol. 44: 93-225.

- 1986. Chromosomes of archaeogastropodas (Mollusca: Prosobranchia), with some remarks on their cytotaxonomy and phylogeny. Publ. Seto. Mer. Biol. Lab. 31: 191-267.

Pasantes, J., Martinez-Exposito, M. J. and Mendez, J. 1996. C-band polymorphism in the chromosomes of the mussel Mytilus galloprovincialis Lmk. Caryologia 49: 233-245.

Rasotto, M., Altieri, D. and Colombera, D. 1981. I cromosomi spermatocitari di 16 specie appartenenti alla classe Pelecypoda. Atti. Congr. Soc. Malac. Ital., Salice Terme (Pavia). 113-127.

Rodriguez-Juiz, A., Torrado, M. and Mendez, J. 1996. Genome size variation in bivalve molluscs determined by flow cytometry. Marine Biology 126: 489-497.

Thiriot-Quievreux, C. and Ayraud, N. 1982. Les caryotypes de quelques especes de Bivalves et de Gastropodes marins. Mar. Biol. 70: 165-175.

— 1984. Les caryotypes de quelques Ostreidae et Mytilidae. Malacologia 25: 465-476.

- 1994. Advances in cytogenetics of aquatic organisms. In: Genetics and evolution of aquatic organisms. A. R. Beaumont (ed.). Chapman \& Hall. pp. 369-388.

- 2002. Review of the literature on bivalve cytogenetics in the last ten years. Cah. Biol. Mar. 43: 17-26.

Vitturi, R., Gianguzza, P., Colomba, M. and Riggio, S. 2000. Cytogenetics characterization of Brachidontes pharaonis (Fisher P., 1870): Karyotype, banding and fluorescent in situ hybridization (Fish) (Mollusca-Bivalvia-Mytilidae). Ophelia 52: 213-220.

Wang, M., Zheng, J. and Li, Y. 1998. The chromosome effect of taxicity of monocrotophos on Ostrea cucullata. J. Ocean Uni. of Qingda 28: 75-81. 